\title{
Induction motor efficiency maximizing based on torque per power index
}

\author{
Najimaldin M. Abbas ${ }^{1}$, Mohammed Obaid Mustafa², Ali M. Shakor ${ }^{1}$ \\ ${ }^{1}$ Department of Electrical Engineering, University of Kirkuk, Kirkuk, Iraq \\ ${ }^{2}$ Department of Electrical Engineering, College of Engineering, University of Mosul, Mosul, Iraq
}

\begin{tabular}{l} 
Article Info \\
\hline Article history: \\
Received Oct 6, 2021 \\
Revised Dec 20, 2021 \\
Accepted Jan 6, 2022 \\
\hline Keywords: \\
Efficiency maximizing \\
Energy optimzaition \\
Induction motor \\
Maximum torque
\end{tabular}

\begin{abstract}
In this paper, efficiency maximization of induction motor variable frequency speed regulation system based on torque per power (TPP) index is proposed. The detail of the mathematical model of the induction motor considering the iron loss and the rotor field orientation, the relationship between the motor torque loss power ratio and the motor speed and slip frequency presented. The functional relationship between the torque loss power ratio and the motor speed and slip is derived, and the derivative is obtained to find the optimal slip frequency corresponding to the maximum value. The simulation model and experimental platform of the control system were built in Matlab/Simulink to verify the effectiveness of the method. The result approved the torque loss power ratio takes the maximum value, the high energy efficiency operation with the minimum power loss of the motor control system is realized.
\end{abstract}

This is an open access article under the CC BY-SA license.

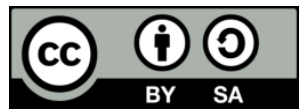

\section{Corresponding Author:}

Najimaldin M. Abbas

Department of Electrical Engineering, University of Kirkuk

Kirkuk, Iraq

Email: dralbyati@uokirkuk.edu.iq

\section{INTRODUCTION}

In industrial production, induction motors often use constant voltage-frequency ratio and variable frequency speed regulation methods, which can achieve smooth speed regulation of induction motors in a larger range [1], [2]. The constant voltage-frequency ratio control method has the characteristics of simple software and hardware implementation and high-cost performance, and is widely used to drive loads that do not require high dynamic performance [3], [4]. Induction motors are more efficient when running near the rated operating point (rated load and rated speed), but in most actual production, the motor runs at a nonrated operating point. The induction motor variable frequency speed regulation systems do not achieve optimal operation of energy efficiency and a lot of electrical energy lost and the operating efficiency of the motor will significantly decrease. Ha et al. [5] introduce energy efficiency optimization methods in the variable frequency speed regulation system, which can reduce the power loss during the operation of the motor and improve the operating efficiency of the motor.

Many research focus on energy efficiency optimization methods and different the relationship of the operating efficiency of the motor with the slip frequency and the iron loss [6]-[9]. When considering the iron loss, a resistor is connected in parallel in the equivalent circuit of the induction motor to represent the iron loss, and then the energy efficiency optimization method of the induction motor is analyzed, which is called the loss model controller (LMC) [10], [11]. The energy efficiency optimization effect of this kind of method is very dependent on the accuracy of the motor parameters, and is usually optimized for efficiency when the motor is running below the fundamental frequency. In order to improve the efficiency of the motor running 
above the fundamental frequency, a control strategy of maximum torque per Ampere (MTPA) is proposed based on the theory of minimum current, which can realize the energy efficiency optimization of the minimum stator current when the motor is under field weakening effect control [12]-[17].

This paper focused on efficiency optimization method of induction motor variable frequency speed regulation system based on torque per power (TPP). The the mathematical model the index derivation between torque and loss power ratios based on of LMC's induction motor. The simulation result of motor speed and slip frequency is analyzed using both proposed index and in induction motor V/f variable frequency speed regulation system. The results of simulation and experiment show that this method can effectively improve the energy-saving effect of the motor operation while maintaining the control performance of the V/f variable frequency speed regulation system, and ensure the energy-efficient operation of the motor.

\section{RELATED WORK}

\subsection{Induction motor $V / f$ control}

In the LMC method, the iron loss is usually represented by an equivalent resistance connected in parallel to the mutual inductance branch as shown in Figure 1. The motor will produce iron loss in actual operation. The existence of iron loss will affect various performances of the motor control system, especially the operating efficiency of the motor [18]. The torque and power loss of the induction motor can be represented by the motor parameters, speed, slip and current including the equivalent resistance [19]-[22]. Refer to the control idea of MTPA, obtain the expression of torque and power loss ratio and simplify it. Take the derivative of the slip to get the maximum value of the torque loss power ratio. The maximum torque loss power ratio is related to the speed and slip, combined with the induction motor's V/f variable frequency speed regulation system, to realize the energy efficiency optimization of the induction motor.

The error between the actual slip frequency $\omega$ and the optimal slip frequency passes through the compensation voltage regulator, and its output is the voltage compensation value, which is used to compensate the stator voltage amplitude. The general pulse width modulation (PWM) pulse modulation method is used to control the switching state of the inverter, control the voltage of the input motor, and then control the operation of the motor, so that the motor runs in the state of optimal energy efficiency [21].

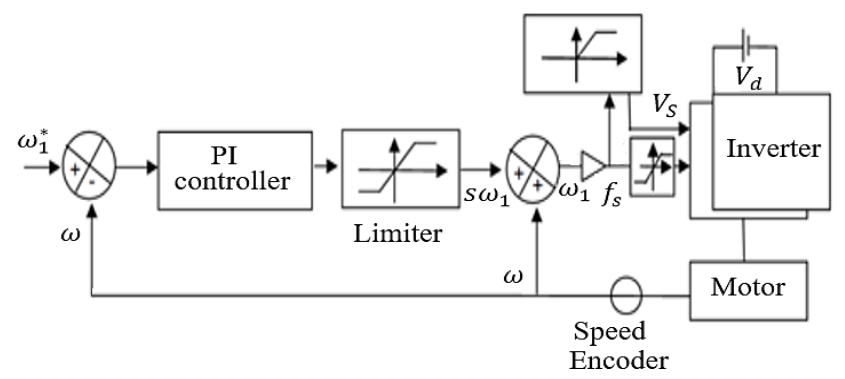

Figure 1. Block diagram of proposed optimization control principle of constant V/f ratio

\subsection{Equivalent circuit of induction motor}

An induction motor's equivalent circuit is similar to a transformer's equivalent circuit since the power transfer from side to other. The equivalent circuit parameters can be used to find efficiency, torque and losses. Moreover, the equivalent circuit of the induction motor established considering the stator iron loss, and after transforming the coordinate, the equivalent circuit in the $d q$ coordinate system is shown in Figure 2 [23].
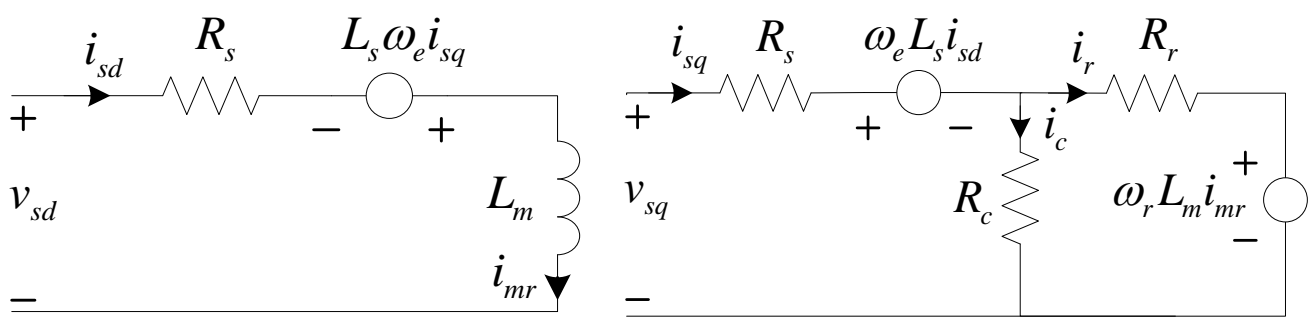

Figure 2. Equivalent circuit of induction motor ( $d q$ axis) [24] 
The mathematical model of induction motor can be obtained based on Figure 2 and the voltage equation will be as (1) [24], [25]:

$$
\left[\begin{array}{l}
u_{s d} \\
u_{s q}
\end{array}\right]=\left[\begin{array}{cccc}
R_{s} & 0 & p & -\omega_{s} \\
0 & R_{s} & \omega_{1} & p
\end{array}\right]\left[\begin{array}{c}
i_{s d} \\
i_{s q} \\
\psi_{s d} \\
\psi_{s q}
\end{array}\right]
$$

flux, as shown in (2):

$$
\left[\begin{array}{l}
\psi_{s d} \\
\psi_{s q}
\end{array}\right]=\left[\begin{array}{cccc}
L_{l s} & 0 & L_{m} & 0 \\
0 & L_{l s} & 0 & L_{m}
\end{array}\right]\left[\begin{array}{c}
i_{s d} \\
i_{s q} \\
i_{L m d} \\
i_{L m q}
\end{array}\right]
$$

current, as shown in (3):

$$
\left\{\begin{array}{l}
i_{L m d}+i_{R m d}=i_{s d}+i_{s d} \\
i_{L m q}+i_{R m q}=i_{s q}+i_{r q}
\end{array}\right.
$$

electromagnetic torque (4):

$$
T_{e}=n_{p} \frac{L_{m}}{L_{r}} \psi_{r d}\left(i_{s q}-i_{R m q}\right)-\psi_{r q}\left(i_{s d}-i_{R m d}\right)
$$

motor input power (5):

$$
P_{\text {input }}=u_{s d} i_{s d}+u_{s q} i_{s q}
$$

where, $u_{s d}$ and $u_{s q}$ are the $d q$ - axis stator voltage; $\omega_{s}$ is the angular frequency of the synchronous speed; $i_{s d}, i_{s q}, i_{r d}$ and $i_{r q}$ are the stator and rotor currents of the $d q$ axis respectively; $R_{s}, R_{r}$ and $R_{m}$ are the stator and rotor resistance and the equivalent resistance of iron loss respectively; $L_{s}, L_{r}$ and $L_{m}$ are the stator and rotor self-inductance and mutual inductance; $L_{l s}$ and $L_{l r}$ are the stator and rotor leakage inductances respectively; $i_{R m d}$ and $i_{R m q}$ are the iron loss equivalent currents of the $d q$ axis respectively; $i_{L m d}, i_{L m q}$ is the $d q$-axis excitation current; $\psi_{s d}, \psi_{s q}, \psi_{r d}$ and $\psi_{r q}$ are the $d q$-axis stator and rotor flux linkages $\omega_{r}$ is the angular frequency of the rotor speed; $\omega=\omega_{s}-\omega_{r}$ is the slip angular frequency,

$$
P_{\text {output }}=T_{e} \omega_{r} / n_{p}
$$

where, $P_{\text {output }}$ is the motor output power; $T_{e}$ is output torque.

\section{PROPOSED METHODS}

When the induction motor adopts the constant voltage-frequency ratio control method, the torque is proportional to the slip. The motor control system adopts the closed-loop speed control to ensure the system has no static difference. When the motor is running in a steady state, the torque and speed are the same. If the power loss of the control system can be reduced by adjusting the slip, then the energy-efficient operation of the induction motor can be realized and the energy-saving effect of the control system can be improved. Starting from the mathematical model of the induction motor considering the iron loss, the torque loss power ratio is taken as the objective function of energy efficiency optimization, and the relationship between the torque loss power ratio and the motor speed and slip is analyzed.

The motor stator and rotor leakage inductance are small and in order to simplify the calculation, so can be neglected, $L_{l s}=L_{l r}=0$. At the sometimes the rotor magnetic field orientation:

$$
\left\{\begin{array}{c}
\psi_{r d}=\psi_{r} \\
\psi_{r q}=0
\end{array}\right.
$$

by substituting (7) into (3), can get: 


$$
\left\{\begin{array}{l}
i_{r d}=0 \\
i_{r q}=0
\end{array}\right.
$$

when the motor is running in a steady state, (1) can get:

$$
\left\{\begin{array}{c}
R_{m} i_{R m d}=-\omega_{1} L_{m} i_{L m q}=0 \\
R_{m} i_{R m q}=-\omega_{1} L_{m} i_{L m d}
\end{array}\right.
$$

by comprehensive (7) and (8) are:

$$
\left\{\begin{array}{c}
i_{r q}=-\frac{\omega_{s l} \psi_{r d}}{R_{r}} \\
i_{L m d}=\frac{\psi_{r d}}{L_{m}}
\end{array}\right.
$$

by Substituting can get:

$$
\begin{aligned}
& u_{s d}=R_{s} i_{s d} \\
& u_{s q}=\left[R_{s}(A+1) \omega+\frac{\omega_{r}}{A R_{m}}\right] L_{m} i_{s d} \\
& i_{s q}=\left[A \omega+\frac{\omega_{r}}{R_{m}}\right] L_{m} i_{s d}
\end{aligned}
$$

where $A$ is equal to $\left(\frac{R_{m}+R_{S}}{R_{m} R_{S}}\right)$.

In the steady state of the induction motor, the output power of the motor can be written as:

$$
\begin{aligned}
& P_{\text {input }}=R_{s} i_{s d}^{2}+u_{s q} i_{s q} \\
& P_{\text {output }}=T_{e} \omega_{r} / n_{p}
\end{aligned}
$$

then the motor torque the is:

$$
T_{e}=\frac{\omega n_{p} L_{m}^{2}}{R_{r}} i_{s d}^{2}
$$

so, there is:

$$
\frac{T_{e}}{P_{\text {Loss }}}=\frac{B \omega_{s l}}{R_{S}+B \omega^{2}+C \omega \omega_{r}+D \omega_{r}^{2}}
$$

where, $B=\left(n_{p} L_{m}^{2}\right) / R_{r} ; C=A R_{s} L_{m}^{2}(A+1) ; D=\frac{2 A L_{m}^{2} R_{s}}{R_{m}}+\frac{2 L_{m}^{2}}{R_{m}} ; E=\frac{L_{m}^{2}}{A R_{m}^{2}}$. By derivation from (17) when the motor runs stably a function of the motor speed and the slip angle frequency. The power loss is the smallest and the torque loss to power ratio is the largest which approximately equal to zero.

$$
\frac{\partial}{\partial \omega}\left(\frac{T_{e}}{P_{\text {loss }}}\right)=0
$$

Then, it can be seen that there is an optimal slip angle frequency, so that under the torque load.

$$
\omega^{*}=\sqrt{\frac{R_{S}+E \omega_{r}^{2}}{C}}=\sqrt{\frac{\frac{R_{S}}{L_{m}^{2}+\frac{\omega_{r}^{2}}{A R_{m}^{2}}}}{R_{S} A^{2}+A}}
$$

Where $\omega^{*}$ represent the optimal slip value which related to the parameters and speed of the induction motor, and is not affected by the motor load, which can achieve the maximum motor efficiency at the full speed range.

In this study the induction motor maximum efficiency model using the constant V/f ratio control system with some assumptions is needed to simplify the mode as:

a. Ignoring the spatial harmonics. 
b. Ignoring the excitation saturation by considering the self-inductance and mutual inductance of each winding are both are constant.

c. Considering the influence of stator excitation magnet loss, connect an equivalent resistance $R_{m}$ of iron loss in parallel in the excitation circuit, and also ignore the influence of temperature, magnetic saturation and other factors on iron loss, which is represented by a constant value.

\section{RESULT AND DISCUSSION}

\subsection{Simulation result}

In order to verify the proposed TPP on the induction motor the energy efficiency optimization compared to constant V/f ratio control system. The induction motor parameters in the simulation model are shown in Table 1, as shown in Figure 3. Where: $K_{P 1}=1, K_{I 1}=0.0013 ; K_{P 2}=13, K_{I 2}=0.51$. Figure 4 shows the optimal slip frequency calculation module according to (19).

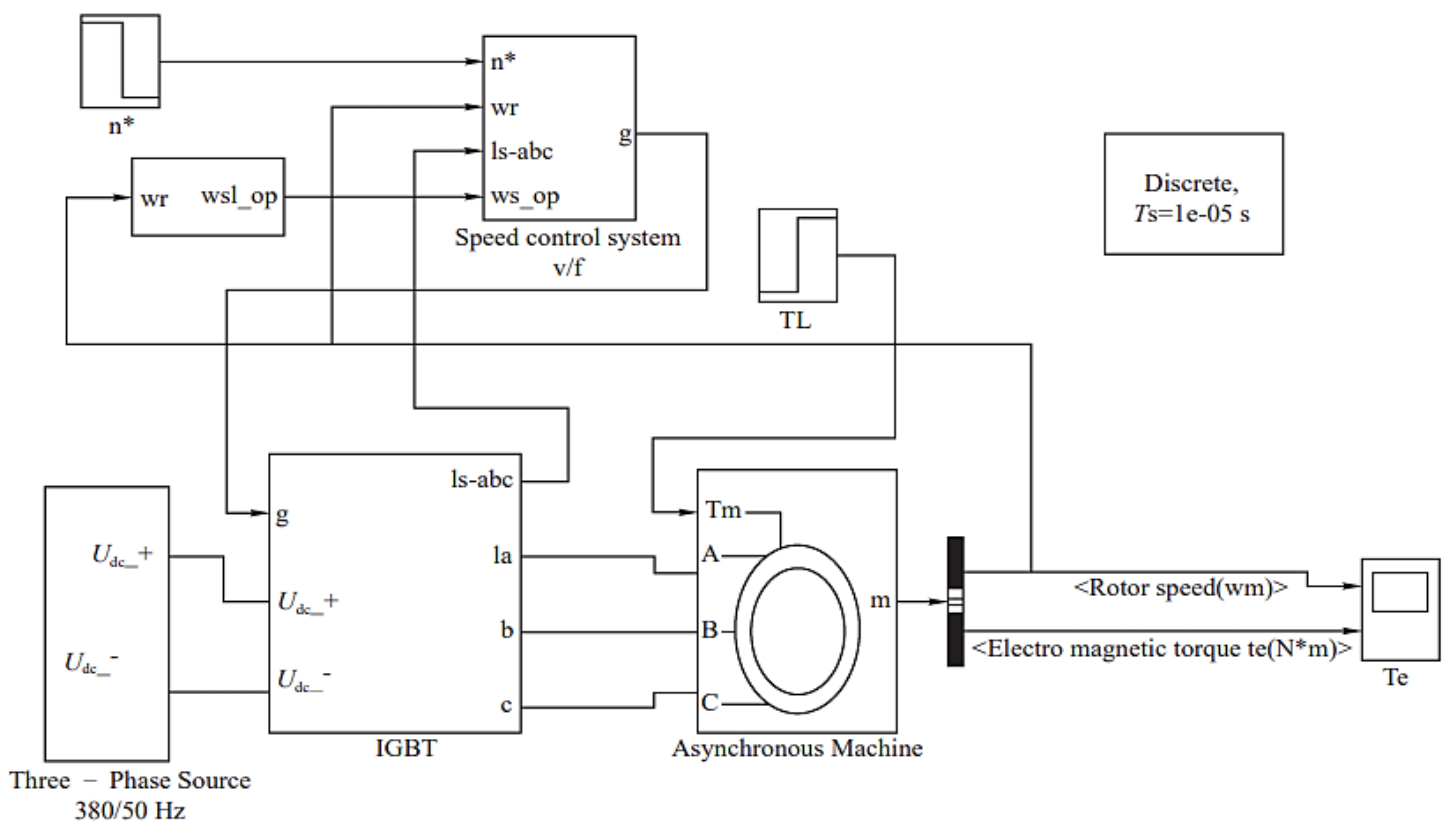

Figure 3. Induction motor simulation model

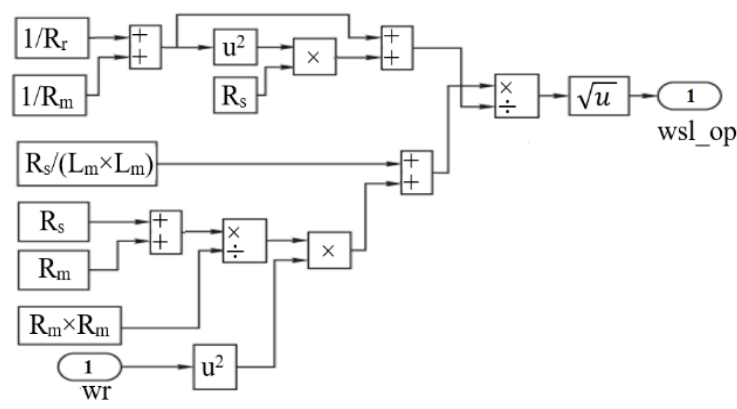

Figure 4. The simulation model of the speed controller and the compensation voltage regulator

Table 1. Motor parameters

\begin{tabular}{llll}
\hline \multicolumn{1}{c}{ Parameter } & \multicolumn{1}{c}{ value } & \multicolumn{1}{c}{ Parameter } & \multicolumn{1}{c}{ value } \\
\hline Power & $10 \mathrm{~kW}$ & Stator resistance & $0.5247 \Omega$ \\
Supply voltage & $380 \mathrm{~V}$ & Stator inductance & $0.005 \mathrm{H}$ \\
Pair Pole $\mathrm{p}$ & 2 & Rotor resistance & $0.3018 \Omega$ \\
Moment of inertia & $0.24 \mathrm{~J} / \mathrm{kg} \cdot \mathrm{m}^{2}$ & Rotor inductance & $0.0051 \mathrm{H}$ \\
Mutual resistance & $49 \Omega$ & Mutual inductance & $0.093 \mathrm{H}$ \\
\hline
\end{tabular}


The motor is set to start at no load, and the initial speed is set at $150 \mathrm{rad} / \mathrm{s}$; when the motor reaches steady state operation, the TPP-based energy efficiency optimization control module is started at $2 \mathrm{~s}$; the load torque is 100 N.m at $3 \mathrm{~s}$; at $5 \mathrm{~s}$ the motor speed suddenly changes to $100 \mathrm{rad} / \mathrm{s}$. From Figure 5(a), it can be seen that the motor reaches a stable operating state at about $1.25 \mathrm{~s}$. In the steady state, the motor speed is a given speed of 140 $\mathrm{rad} / \mathrm{s}$, and the speed basically has no overshoot and no oscillation. The system adds energy efficiency optimization control in $2 \mathrm{~s}$, and the speed of the motor quickly returns to the original stable state after slight oscillation, and the speed remains unchanged; the torque setting changes at $3 \mathrm{~s}$, and the slip becomes larger due to the use of V/f control. As a result, the speed drops to $133 \mathrm{rad} / \mathrm{s}$; at $5 \mathrm{~s}$, the motor speed reference is reduced from $150 \mathrm{rad} / \mathrm{s}$ to 100 $\mathrm{rad} / \mathrm{s}$, and the output speed also changes immediately, but due to the slip caused by the load torque, the actual speed is $95 \mathrm{rad} / \mathrm{s}$. In Figure 5(b), since the motor is starting at no load, the current in the starting phase is relatively large, resulting in a relatively large starting torque of the motor. When the speed of the motor reaches a given time at $1.25 \mathrm{~s}$, the output torque of the motor is $0 \mathrm{~N} \bullet \mathrm{m}$; When the TPP control is started at $2 \mathrm{~s}$, the motor torque has some pulsation, but it does not affect; the motor torque setting is changed to $100 \mathrm{~N} . \mathrm{m}$ at $3 \mathrm{~s}$, and the output torque responds immediately. When the speed changes, the output torque of the motor is affected, and there is oscillation, but it quickly returns to stability. Figure 5(c) is the comparison of TPP and V/f power loss during the motor starting and speed regulation process, due to system oscillation, the power loss changes greatly. When the motor is running in a steady state, the power loss curve is stable.

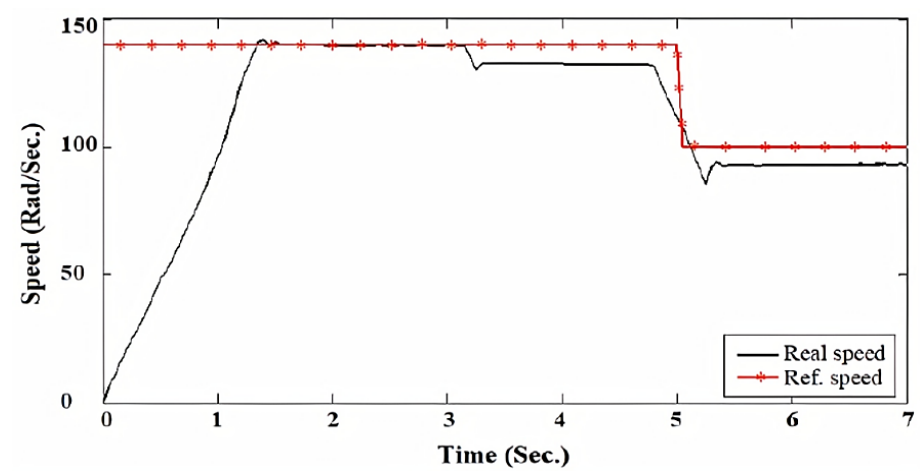

(a)

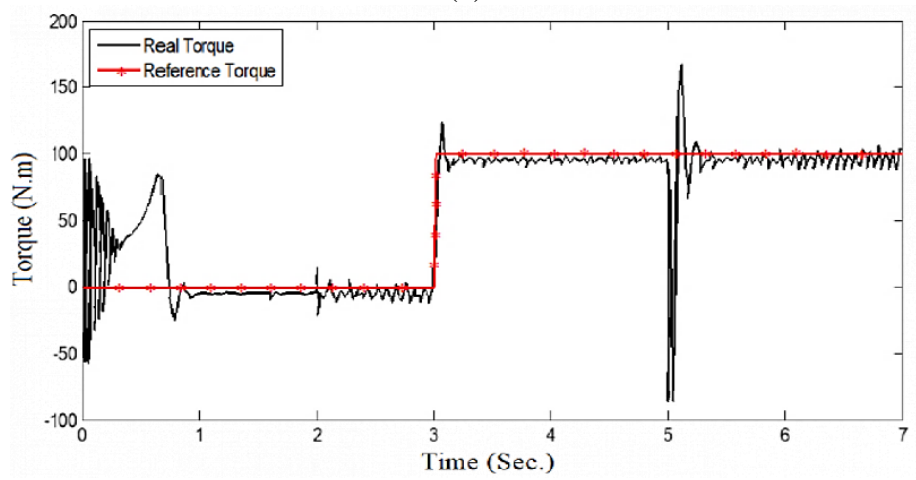

(b)

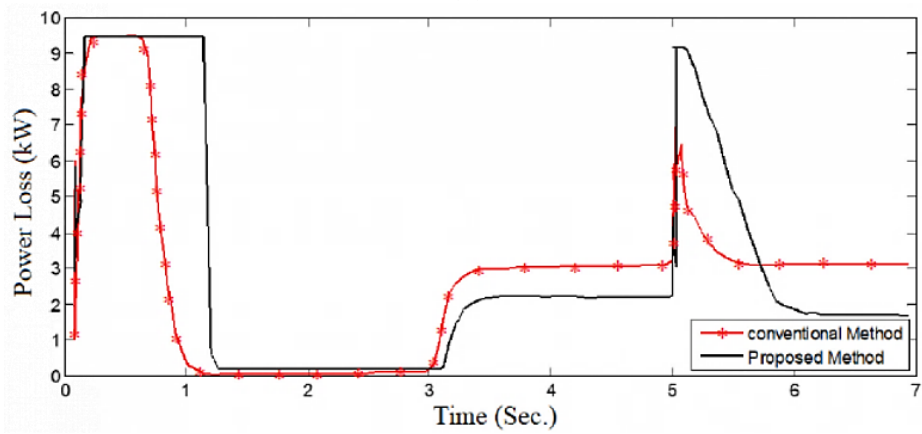

(c)

Figure 5. Simulation experiment results, (a) simulation results of motor speed, (b) motor torque simulation results, and (c) power loss simulation results 
From Figure 5 it can be seen that when the motor load is 100 N.m and $150 \mathrm{rad} / \mathrm{s}$, the power loss of the motor is reduced from $3 \mathrm{~kW}$ to $2.3 \mathrm{~kW}$, which is a reduction of $0.7 \mathrm{~kW}$; when the speed of the motor drops to $100 \mathrm{rad} / \mathrm{s}$, the power loss of the motor from $2.9 \mathrm{~kW}$ to $1.8 \mathrm{~kW}$, a reduction of $1.1 \mathrm{~kW}$. It can be seen that the TPP control strategy proposed in this paper has a significant effect on energy efficiency optimization in the induction motor $\mathrm{V} / \mathrm{f}$ control system.

\subsection{Experimental result}

The experimental results of the induction motor based on the TPP energy efficiency optimization method is shown in Figure 6. In Figure 6, the represents the variation of the power loss of the ordinary V/f system with torque and speed, and the dotted line represents the power loss of the V/f control system optimized by TPP energy efficiency.

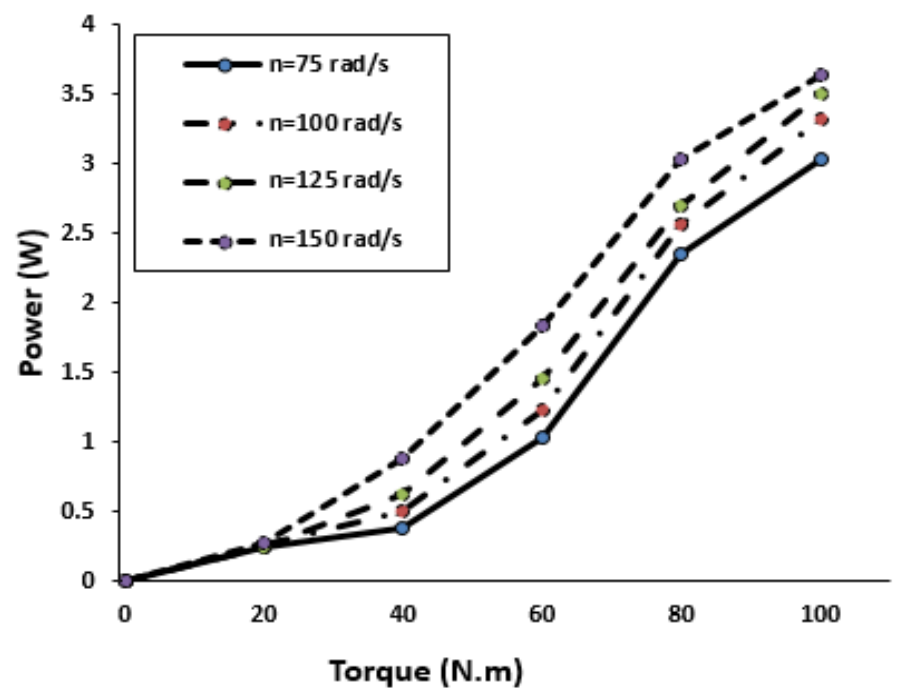

Figure 6. Experimental results of power loss under motor speed

It can be seen from the results of the experiment that as the load of the motor increases, the power loss of the motor also increases, which is caused by the change of the stator current with the torque; and under the same load torque, the higher the speed, The loss of the motor also becomes higher. By analyzing the power loss comparison chart, it can be found that then the load and torque are the same, compared with the traditional V/f control system. The power has been significantly reduced, achieving the goal of the maximum torque loss power ratio, and realizing the optimization of the energy efficiency of the induction motor.

\section{CONCLUSION}

This paper introduces the energy efficiency optimization methods of MTPA induction motors, takes the induction motor equivalent circuit considering iron loss as the basis of analysis, and imitates the maximum efficiency optimization idea of MTPA. Under a certain load torque, the minimization of power loss is the maximum efficiency optimization.

The goal of the method is to propose an energy efficiency optimization method for TPP's induction motor variable frequency speed regulation system. The advantage of this method is that the analysis process of the motor energy efficiency optimization method is simple, which is convenient for the realization of the software and hardware of the control system. However, because the iron loss of the motor is ignored, the energy efficiency optimization effect in practical applications is not ideal. The simulation and experimental result approve the effectiveness of the TPP efficiency optimization method for improving the efficiency maximizing and energy saving. 


\section{ACKNOWLEDGEMENTS}

The authors grarfull to Department of Electrical Engineering, University of Kirkuk and University of Mosul for their support.

\section{REFERENCES}

[1] E. C. Quispe, I. D. López, F. J. T. E. Ferreira, and V. Sousa, "Unbalanced Voltages Impacts on the Energy Performance of Induction Motors," International Journal of Electrical and Computer Engineering (IJECE), vol. 8, no. 3, p. 1412, Jun. 2018, doi: 10.11591/ijece.v8i3.pp1412-1422.

[2] A. Dalabeeh, A.-M. Anwar, T. M. Younes, A. Al-Rawashdeh, and A. Hindi, "Increasing the required slip range of wound induction generator in wind power systems," Bulletin of Electrical Engineering and Informatics, vol. 9, no. 2, pp. 436-442, Apr. 2020, doi: 10.11591/eei.v9i2.1795

[3] S. S. Keream, A. N. Abdalla, and M. R. Bin Daud, "Nonlinear dynamic inverse controller based in field oriented with SVPWM current control," Journal Science \& Technology, vol. 25, pp. 37-44, 2017.

[4] M. Rekha and M. K. Kumar, "Variable frequency drive optimization using torque ripple control and self-Tuning PI controller with PSO," International Journal of Electrical and Computer Engineering (IJECE), vol. 9, no. 2, p. 802, Apr. 2019, doi: 10.11591/ijece.v9i2.pp802-814.

[5] V. T. Ha, T. T. Minh, N. T. Lam, and N. H. Quang, "Experiment based comparative analysis of stator current controllers using predictive current control and proportional integral control for induction motors," Bulletin of Electrical Engineering and Informatics, vol. 9, no. 4, pp. 1662-1669, Aug. 2020, doi: 10.11591/eei.v9i4.2084.

[6] J.-D. Tan, S.-P. Koh, S.-K. Tiong, K. Ali, and A. Abdalla, "Fuzzy Logic Enhanced Direct Torque Control with Space Vector Modulation," Indonesian Journal of Electrical Engineering and Computer Science, vol. 11, no. 2, p. 704, Aug. 2018, doi: 10.11591/ijeecs.v11.i2.pp704-710.

[7] S. Aryza, A. N. Abdallah, Z. bin Khalidin, Z. Lubis, and M. Jie, “A Fast Induction Motor Speed Estimation based on Hybrid Particle Swarm Optimization (HPSO)," Physics Procedia, vol. 25, pp. 2109-2115, 2012, doi: 10.1016/j.phpro.2012.03.357.

[8] J. Li, S. Nie, Q. Meng, and H. Ren, "Efficiency optimization of induction motors based on online identification of iron loss equivalent resistance via dual extended Kalman filter," in 2016 IEEE Region 10 Conference (TENCON), Nov. 2016, pp. 33093312, doi: 10.1109/TENCON.2016.7848664.

[9] J. Li, F.-F. Xiao, and S.-Q. Zhang, "Simplified loss model control efficiency optimization algorithm for vector control induction motor drives," in IECON 2017 - 43rd Annual Conference of the IEEE Industrial Electronics Society, Oct. 2017, pp. 5178-5183, doi: 10.1109/IECON.2017.8216895.

[10] Ramdan Razali, "Improving squirrel cage induction motor efficiency: Technical review," International Journal of the Physical Sciences, vol. 7, no. 8, pp. 1129-1140, Feb. 2012, doi: 10.5897/ijps11.395.

[11] A. Jidin, K. Abdul Karim, K. Rahim, L. R. L. Victor Raj, S. Ramahlingam, and T. Sutikno, "A Review on Constant Switching Frequency Techniques for Direct Torque Control of Induction Motor," Indonesian Journal of Electrical Engineering and Computer Science, vol. 7, no. 2, p. 364, Aug. 2017, doi: 10.11591/ijeecs.v7.i2.pp364-372.

[12] M. Cacciato, A. Consoli, G. Scarcella, and G. Scelba, "Indirect Maximum Torque per Ampere control of induction motor drives," in 2007 European Conference on Power Electronics and Applications, 2007, pp. 1-10, doi: 10.1109/EPE.2007.4417542.

[13] H. Farhan Rashag, N. M.L. Tan, S. P. Koh, A. N. Abdalla, K. H. Chong, and S. K. Tiong, "DTC-SVM Based on PI Torque and PI Flux Controllers to Achieve High Performance of Induction Motor," Research Journal of Applied Sciences, Engineering and Technology, vol. 7, no. 4, pp. 875-891, Jan. 2014, doi: 10.19026/rjaset.7.330.

[14] H. A. Mohamed and H. M. D. Habbi, "Power quality of dual two-level inverter fed open end winding induction motor," Indonesian Journal of Electrical Engineering and Computer Science, vol. 18, no. 2, p. 688, May 2020, doi: 10.11591/ijeecs.v18.i2.pp688-697.

[15] M. Sertsöz and M. Kurban, "Energy efficiency of a special squirrel cage induction motor," in Green Energy and Technology, 2018, pp. 219-229.

[16] M. Sahu and P. K. Choudhary, "Efficiency optimization of induction motor drive," in National conference on Innovative Paradigms in Engineering \& Technology - NCIPET 2013, 2013, pp. 55-59.

[17] G. Joshi and P. P. A J, “ANFIS controller for vector control of three phase induction motor," Indonesian Journal of Electrical Engineering and Computer Science, vol. 19, no. 3, p. 1177, Sep. 2020, doi: 10.11591/ijeecs.v19.i3.pp1177-1185.

[18] G. O. Garcia, R. M. Stephan, and E. H. Watanabe, "Comparing the indirect field-oriented control with a scalar method," IEEE Transactions on Industrial Electronics, vol. 41, no. 2, pp. 201-207, Apr. 1994, doi: 10.1109/41.293880.

[19] M. Kollipara and V. N. S. R. Kolluru, "Invention into the AC Voltage Regulator with V/F Technique for Induction Motor Starting Applications," Bulletin of Electrical Engineering and Informatics, vol. 4, no. 4, pp. 298-303, Dec. 2015, doi: 10.11591/eei.v4i4.513.

[20] M. Kaddari, M. El Mouden, A. Hajjaji, and S. Abdellah, "Estimation efficiency of rewound induction motors in situ using a numerical model," Bulletin of Electrical Engineering and Informatics, vol. 9, no. 5, pp. 1783-1793, Oct. 2020, doi: 10.11591/eei.v9i5.2349.

[21] S. Aryza, A. N. Abdalla, Z. Khalidin, and Z. Lubis, "Adaptive Speed Estimation of induction motor Based on Neural network Inverse Control," Procedia Engineering, vol. 15, pp. 4188-4193, 2011, doi: 10.1016/j.proeng.2011.08.786.

[22] C. C. Chan, "The State of the Art of Electric, Hybrid, and Fuel Cell Vehicles," Proceedings of the IEEE, vol. 95, no. 4, pp. 704718, Apr. 2007, doi: 10.1109/JPROC.2007.892489.

[23] A. N. Abdalla, Z. Lubis, M. Bin, Z. M. Ali, M. Azlan, and M. Hussin, "A new series-parallel hybrid electric vehicle configuration based on an induction motor coupled to a DC machine," Scientific Research and Essays, vol. 5, no. 24, pp. 4034-4193, 2010.

[24] T. H. Nguyen, J. R. Son, K. P. H. Kim, N. S. Jeong, H. K. Kim, and S. B. Kim, "Study on Hybrid Method for Efficiency Optimization of Induction Motor Drives," in Lecture Notes in Electrical Engineering, vol. 465, 2018, pp. 883-893.

[25] T. K. Boukas and T. G. Habetler, "High-performance induction motor speed control using exact feedback linearization with state and state derivative feedback," in IEEE Transactions on Power Electronics, vol. 19, no. 4, pp. 1022-1028, July 2004, doi: 10.1109/TPEL.2004.830042. 


\section{BIOGRAPHIES OF AUTHORS}

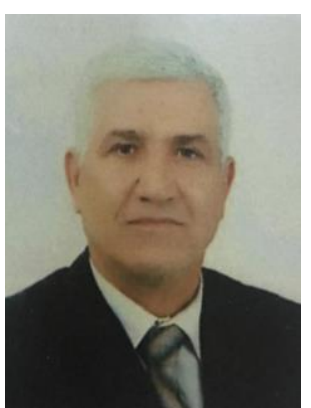

Najimaldi M. Abbas (iD SC P received M.Sc in Electrical Engineering from Baghdad University, Baghdad, Iraq in 1978 and Ph.D in Electrical Engineering from Southampton university Electrical Engineering, UK, 1989. Currently working as assistance Prof. with department of Electrical Engineering, University of Kirkuk, Iraq. Research interested in Electrical machine, control, Modelling, artificial intelligence, and optimization. He can be contacted at email: dralbyati@uokirkuk.edu.iq.

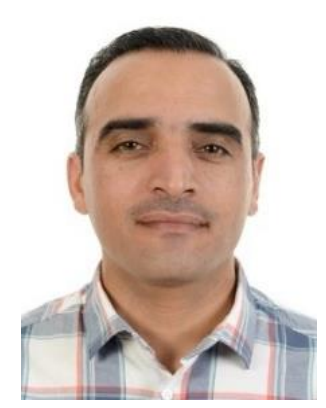

Mohammed Obaid Mustafa (D) 81 SC P received M.Sc in Electrical Engineering from Mosul University, Mosul, Iraq in 2002 and Ph.D in Control Engineering from Luleå University of Technology, Sweden, 2015. Currently working as Lecturer. with department of Electrical Engineering, University of Mosul, Iraq. Research interested in Control, optimization, Modelling and Machine learning. He can be contacted at email: mohammed.obaid@uomosul.edu.iq.

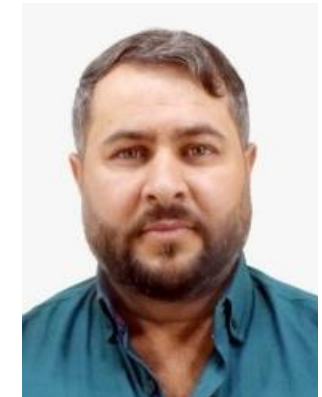

Ali M. Shakor (DD 8D SC P , received BSc in Electrical Engineering from Tikret University, Tikret, Iraq in 2009 and M.Sc in Electrical Engineering from California state University Fullerton, USA, 2017. Currently working as Ass. Lecturer. with department of Electrical Engineering, University of Kirkuk, Iraq. Research interested in Control, optimization, Modelling and Machine learning. He can be contacted at email: ali.doub88@uokirkuk.edu.iq. 